\title{
Low-T Mechanisms of Ammonia Synthesis on $\mathrm{Co}_{3} \mathrm{Mo}_{3} \mathrm{~N}$
}

\author{
Constantinos D. Zeinalipour-Yazdi, ${ }^{*}{ }^{\dagger}$ Ji] Justin S. J. Hargreaves, ${ }^{\ddagger \oplus}$ and C. Richard A. Catlow ${ }^{*},, \S$ \\ ${ }^{\dagger}$ Department of Chemistry, University College London, London, WC1H 0AJ, United Kingdom \\ ${ }^{\ddagger}$ WestCHEM, School of Chemistry, University of Glasgow, Joseph Black Building, Glasgow G12 8QQ United Kingdom \\ ${ }^{\S}$ School of Chemistry, Cardiff University, Cardiff CF10 1AD, United Kingdom
}

\section{Supporting Information}

\begin{abstract}
Dispersion-corrected periodic DFT calculations have been applied to elucidate the Langmuir-Hinshelwood (dissociative) and an EleyRideal/Mars-van Krevelen (associative) mechanism for ammonia synthesis over $\mathrm{Co}_{3} \mathrm{Mo}_{3} \mathrm{~N}$ surfaces, in the presence of surface defects. Comparison of the two distinct mechanisms clearly suggests that apart from the conventional dissociative mechanism, there is another mechanism that proceeds via hydrazine and diazane intermediates that are formed by EleyRideal type chemistry, where hydrogen reacts directly with surface activated nitrogen, in order to form ammonia at considerably milder conditions. This result clearly suggests that via surface defects ammonia synthesis activity can be enhanced at milder conditions on one of the most active catalysts for ammonia synthesis.
\end{abstract}

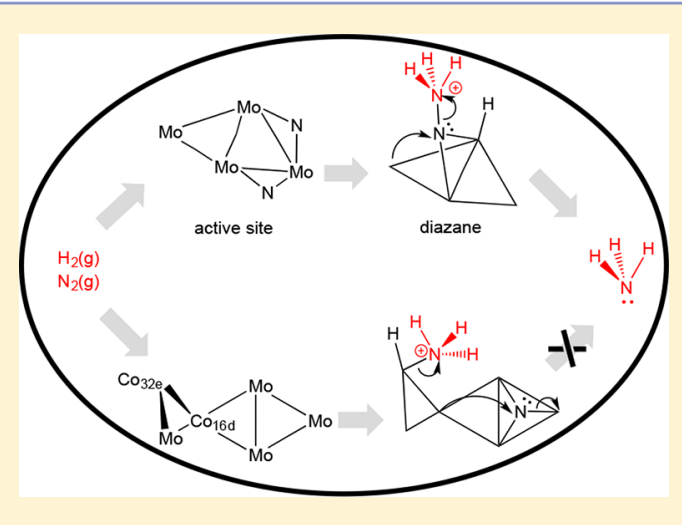

\section{INTRODUCTION}

The development of alternative nitrogen-fixation processes could have a profound economic and environmental impact, as more that $50 \%$ of ammonia for soil fertilizers is produced by man. The other $50 \%$ is produced naturally by nitrogenase ${ }^{1}$ in nitrogen fixation plants where the reduction of $\mathrm{N}_{2}$ occurs by the FeMo-cofactor. ${ }^{2-4}$ Currently ammonia synthesis industrially is achieved mostly via the classical Haber-Bosch (H-B) process, ${ }^{5-7}$ with a $\mathrm{Fe}-\mathrm{K}_{2} \mathrm{O}-\mathrm{Al}_{2} \mathrm{O}_{3}$ catalyst, which operates under high temperatures $\left(>400{ }^{\circ} \mathrm{C}\right)$ and pressures $(150-200$ atm). Some industrial plants have changed to the Kellogg advanced ammonia process that uses a graphite-supported alkali/alkaline-earth promoted $\mathrm{Ru}$ catalyst, which operates at milder conditions but is expensive. ${ }^{8}$ Researchers are now seeking catalytic materials that could potentially produce ammonia at low temperatures $\left(T=200-300{ }^{\circ} \mathrm{C}\right)$ in order to save energy. The generally accepted mechanism for ammonia synthesis on the iron K-promoted Fe catalyst is a LangmuirHinshelwood (L-H) mechanism which is dissociative., ${ }^{9,10}$ An $\mathrm{L}-\mathrm{H}$ mechanism has also been found on the $\mathrm{Ru}(0001)$ surfaces, via density functional theory (DFT) calculations in order to model the $\mathrm{Ru}$-graphite catalyst. ${ }^{11,12}$ The ratedetermining step (RDS) was found to be the activation step for $\mathrm{N}_{2}{ }^{13}$ due to the high bond dissociation enthalpy of $\mathrm{N}_{2}(945$ $\mathrm{kJ} \mathrm{mol}{ }^{-1}$ ) compared to $\mathrm{H}_{2}\left(436 \mathrm{~kJ} \mathrm{~mol}^{-1}\right){ }^{14}$ An associative mechanism has recently been found on $\mathrm{Ru}$ that proceeds through a $-\mathrm{N}_{2} \mathrm{H}$ intermediate. ${ }^{15}$

$\mathrm{Co}_{3} \mathrm{Mo}_{3} \mathrm{~N}$ is known to be a more active catalyst than the one currently used by the industry, especially when doped with cesium. $^{16-20}$ Although the high activity of this and related materials has been established, there is a need to understand its origin and to elucidate the mechanism of ammonia synthesis.
Only a few previous DFT studies have attempted to model the kinetics of ammonia synthesis on this catalyst, based on linearscaling relationships, that correlated the dissociation barrier to the adsorption energy of $\mathrm{N}_{2}{ }^{16,21}$ where an $\mathrm{L}-\mathrm{H}$ mechanism was assumed. ${ }^{13}$ However, a detailed study of the elementary mechanistic steps and the role of surface defects in particular is currently lacking. In two recent DFT studies we have identified possible sites for the adsorption and activation of the reactants of the ammonia synthesis reaction on a model $\mathrm{Co}_{3} \mathrm{Mo}_{3} \mathrm{~N}$ surface with heterogeneity due to surface nitrogen vacancies. ${ }^{22}$ Such vacancies are present in large concentrations even at ambient temperatures (i.e., $10^{13} \mathrm{~cm}^{-2}$ ) and can efficiently activate $\mathrm{N}_{2}{ }^{23}$ Our earlier work found that there are two activation sites for $\mathrm{N}_{2}$, the first is a surface cavity, where $\mathrm{N}_{2}$ is bound side-on a $\mathrm{Co}_{8}$ cluster at the $16 d$ Wyckoff site, where $\mathrm{N}_{2}$ is activated $21 \%$ (as measured by the percentage change in the $\mathrm{N}-\mathrm{N}$ bond length); the second, a somewhat weaker activation site $(11 \%)$ that was found to be located at surface 3f-nitrogen vacancies for which we have suggested that nitrogen vacancies can participate in the elementary reaction steps toward the formation of ammonia. ${ }^{22}$ Indeed, recent DFT studies show that $\mathrm{N}$-vacancies can participate in the mechanism for the electrochemical reduction of ammonia on $\mathrm{Zr}, \mathrm{Nb}, \mathrm{Cr}$, and $\mathrm{V}$ mononitrides ${ }^{24,25}$ and in the two-step solar-energy driven ammonia synthesis on metal-nitrides. ${ }^{26,27}$ Additionally, in a recent DFT study, the electrochemical synthesis of ammonia was studied for the Mars-van Krevelen mechanism on group III-VII transition metal nitrides and a $\mathrm{N}-\mathrm{N}$ was found to be

Received: December 15, 2017

Published: January 8, 2018 
suitable, whereas the other metal nitrides decompose to their pure metals. $^{28}$

\section{RESULTS AND DISCUSSION}

In this communication we have considered a LangmuirHinshelwood (L-H; see Schemes 1 and 3) and an Eley-Rideal/ Mars-van Krevelen (E-R/MvK; see Schemes 2 and 4) mechanism for ammonia synthesis on $\mathrm{Co}_{3} \mathrm{Mo}_{3} \mathrm{~N}-(111)$ surfaces.

Scheme 1. Elementary Reaction Steps for the L-H (Dissociative) Mechanism

$$
\begin{aligned}
& * \stackrel{+\mathrm{N}_{2, \mathrm{~g}}}{\longrightarrow} \mathrm{N}_{2, \mathrm{ads}} \\
& \mathrm{N}_{2, \mathrm{ads}} \longrightarrow 2 \mathrm{~N}_{\mathrm{ads}} \\
& 2 \mathrm{~N}_{\mathrm{ads}} \stackrel{+\mathrm{H}_{2, \mathrm{~g}}}{\longrightarrow} 2 \mathrm{~N}_{\mathrm{ads}}+2 \mathrm{H}_{\mathrm{ads}} \\
& 2 \mathrm{~N}_{\mathrm{ads}}+2 \mathrm{H}_{\mathrm{ads}} \longrightarrow \mathrm{NH}_{\mathrm{ads}}+\mathrm{H}_{\mathrm{ads}}+\mathrm{N}_{\mathrm{ads}} \\
& \mathrm{NH}_{\mathrm{ads}}+\mathrm{H}_{\mathrm{ads}}+\mathrm{N}_{\mathrm{ads}} \longrightarrow \mathrm{NH}_{2, \mathrm{ads}}+\mathrm{N}_{\mathrm{ads}} \\
& \mathrm{NH}_{2, \text { ads }}+\mathrm{N}_{\mathrm{ads}} \stackrel{+\mathrm{H}_{2, \mathrm{~g}}}{\longrightarrow} \mathrm{NH}_{2, \mathrm{ads}}+\mathrm{N}_{\mathrm{ads}}+2 \mathrm{H}_{\mathrm{ads}} \quad \mathbf{F} \\
& \mathrm{NH}_{2, \mathrm{ads}}+\mathrm{N}_{\mathrm{ads}}+2 \mathrm{H}_{\mathrm{ads}} \longrightarrow \mathrm{NH}_{3, \mathrm{ads}}+\mathrm{N}_{\mathrm{ads}}+\mathrm{H}_{\mathrm{ads}} \quad \text { G } \\
& \mathrm{NH}_{3, \text { ads }}+\mathrm{N}_{\mathrm{ads}}+\mathrm{H}_{\mathrm{ads}} \stackrel{-\mathrm{NH}_{3, \mathrm{~g}}}{\longrightarrow} \mathrm{N}_{\mathrm{ads}}+\mathrm{H}_{\mathrm{ads}} \\
& \mathrm{N}_{\mathrm{ads}}+\mathrm{H}_{\mathrm{ads}} \longrightarrow \mathrm{NH}_{\mathrm{ads}} \\
& \mathrm{NH}_{\mathrm{ads}} \stackrel{+\mathrm{H}_{2, \mathrm{~g}}}{\longrightarrow} \mathrm{NH}_{\mathrm{ads}}+2 \mathrm{H}_{\mathrm{ads}} \\
& \mathrm{NH}_{\mathrm{ads}}+2 \mathrm{H}_{\mathrm{ads}} \longrightarrow \mathrm{NH}_{2, \mathrm{ads}}+\mathrm{H}_{\mathrm{ads}} \\
& \mathrm{NH}_{2, \text { ads }}+\mathrm{H}_{\text {ads }} \underset{-\mathrm{NH}_{3, \mathrm{~g}}}{\longrightarrow} \mathrm{NH}_{3, \text { ads }} \\
& \mathrm{NH}_{3, \text { ads }} \stackrel{-\mathrm{NH}_{3, \mathrm{~g}}}{\longrightarrow} *
\end{aligned}
$$

Scheme 2. Elementary Reaction Steps for the E-R/MvK (Associative) Mechanism

$$
\begin{aligned}
& * \stackrel{+\mathrm{N}_{2, \mathrm{~g}}}{\longrightarrow} \mathrm{N}_{2, \mathrm{ads}} \\
& \mathrm{N}_{2, \text { ads }} \stackrel{+\mathrm{H}_{2, \mathrm{~g}}}{\longrightarrow} \mathrm{N}_{2} \mathrm{H}_{2 \text {,ads }} \\
& \mathrm{N}_{2} \mathrm{H}_{2, \text { ads }} \stackrel{+\mathrm{H}_{2, \mathrm{~g}}}{\longrightarrow} \mathrm{N}_{2} \mathrm{H}_{2, \mathrm{ads}}+\mathrm{H}_{2, \text { ads }} \\
& \mathrm{N}_{2} \mathrm{H}_{2, \mathrm{ads}}+\mathrm{H}_{2, \mathrm{ads}} \longrightarrow \mathrm{N}_{2} \mathrm{H}_{3, \text { ads }}+\mathrm{H}_{\mathrm{ads}} \\
& \mathrm{N}_{2} \mathrm{H}_{3, \mathrm{ads}}+\mathrm{H}_{\mathrm{ads}} \stackrel{-\mathrm{NH}_{3, \mathrm{~g}}}{\longrightarrow} \mathrm{N}_{\mathrm{ads}}+\mathrm{H}_{\mathrm{ads}} \\
& \mathrm{N}_{\mathrm{ads}}+\mathrm{H}_{\mathrm{ads}} \longrightarrow \mathrm{NH}_{\mathrm{ads}} \\
& \mathrm{NH}_{\mathrm{ads}} \stackrel{+\mathrm{H}_{2, \mathrm{~g}}}{\longrightarrow} \mathrm{NH}_{\mathrm{ads}}+\mathrm{H}_{2, \mathrm{ads}} \\
& \mathrm{NH}_{\mathrm{ads}}+\mathrm{H}_{2, \mathrm{ads}} \longrightarrow \mathrm{NH}_{2, \mathrm{ads}}+\mathrm{H}_{\mathrm{ads}}
\end{aligned}
$$

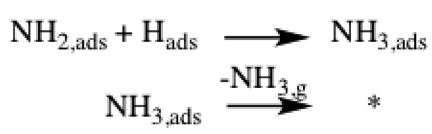

$$
\begin{aligned}
& \mathbf{D}^{\prime} \\
& G^{\prime} \\
& \mathbf{H}^{\prime} \\
& \mathbf{I}^{\prime} \\
& \mathbf{J}^{\prime}
\end{aligned}
$$

In particular, we have applied dispersion-corrected (D3) DFT in order to calculate the potential energy diagram for ammonia synthesis for two mechanistic pathways for ammonia synthesis on the (111)-surfaces of $\mathrm{Co}_{3} \mathrm{Mo}_{3} \mathrm{~N}$ in the presence of surface defects, such as nitrogen vacancies and intrinsic surface cavities. The computational methodology has been described in detail elsewhere. ${ }^{22,23}$ Activation barriers were obtained by the nudged elastic band (NEB) method in which the barrier was modeled first by 10 images to acquire the details of the potential energy surface. Once the various intermediates were found and fully optimized, the transition states were located by a separate NEB run of 3 images. Remarkably, we find that there are two possible mechanisms for ammonia synthesis; the first is the commonly known L-H mechanism ${ }^{8}$ shown in Scheme 3;

Scheme 3. L-H (Dissociative) Mechanism for Ammonia Synthesis on $\mathrm{Co}_{3} \mathrm{Mo}_{3} \mathrm{~N}$
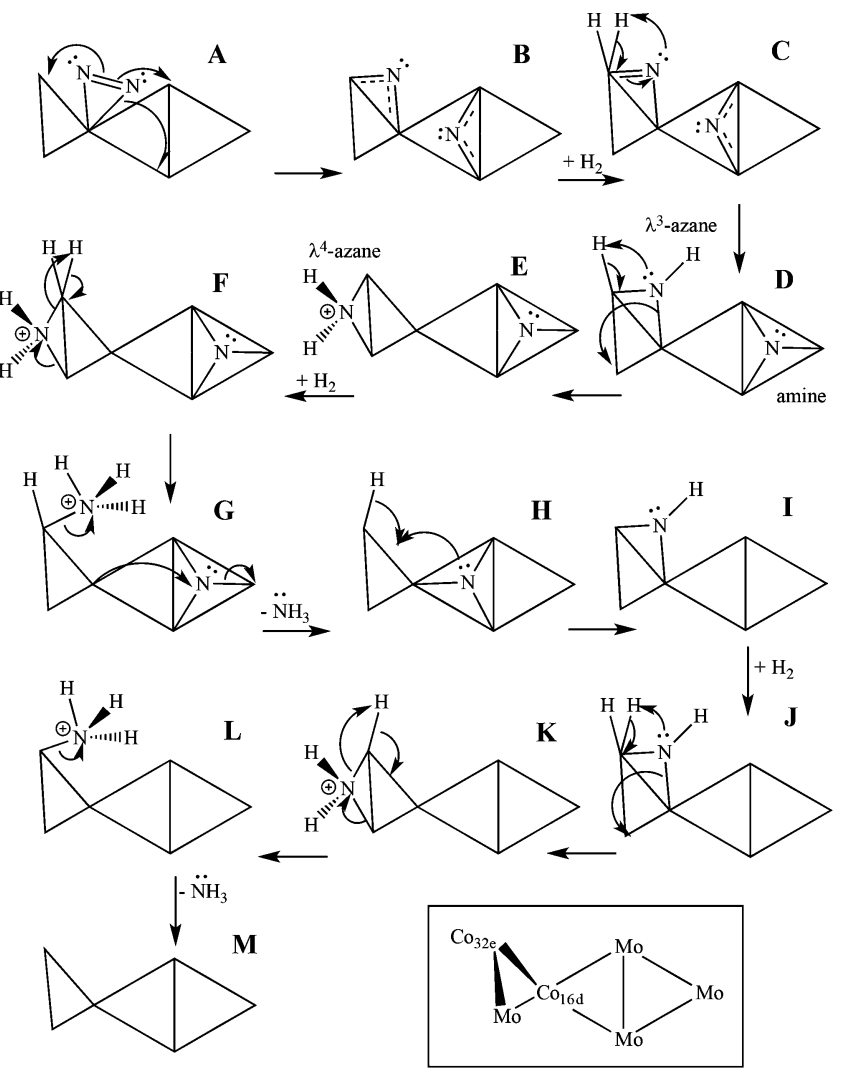

the second resembles an Eley-Rideal/Mars-van Krevelen (associative) mechanism in which surface lattice nitrogen participates as shown in Scheme 4. The relative energy diagram of the two reactions is shown in Figure 1.

L-H (Dissociative) Ammonia Synthesis Mechanism. $\mathrm{N}_{2}$ adsorbs generally less favorably than hydrogen on $\mathrm{Co}_{3} \mathrm{Mo}_{3} \mathrm{~N}$ (111) surfaces. However, at the surface cavity, the adsorption of both $\mathrm{N}_{2}$ and $\mathrm{H}_{2}$ is slightly endothermic: 40 and $21 \mathrm{~kJ} / \mathrm{mol}$, respectively (other less active adsorption sites have exothermic adsorption energies), indicating that some pressure maybe required. A detailed study of the various adsorption sites is given in ref 23, which showed that $\mathrm{H}_{2}$ and $\mathrm{N}_{2}$ can essentially coadsorb at the activation sites; the activation barriers of the L$\mathrm{H}$ mechanism has hydrogenation barriers higher than the mechanism modeled on $\mathrm{Ru}(0001)$, which indicates that at higher- $\mathrm{T}$ there maybe additional reaction mechanisms occurring on nitrogen free $\mathrm{Co}_{3} \mathrm{Mo}_{3} \mathrm{~N}$ surfaces. Therefore, in the $\mathrm{L}-\mathrm{H}$ modeled here the mechanism for $\mathrm{NH}_{3}$ synthesis follows the 
Scheme 4. E-R/MvK (Associative) Mechanism for Ammonia Synthesis on $\mathrm{Co}_{3} \mathrm{Mo}_{3} \mathrm{~N}$
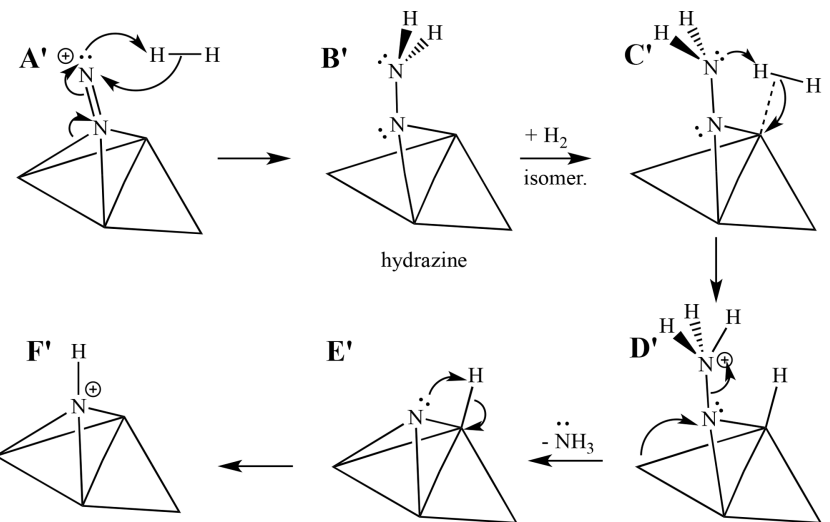

$\lambda^{4}$-azane

$+\mathrm{H}_{2}$
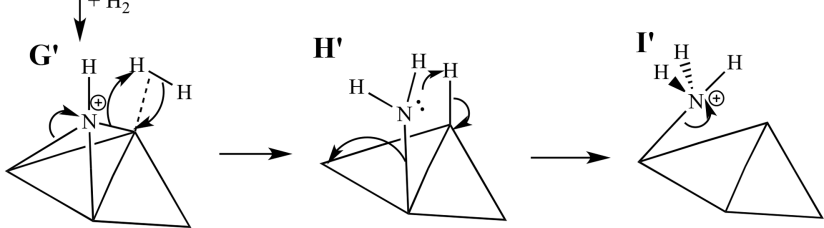

primary amine
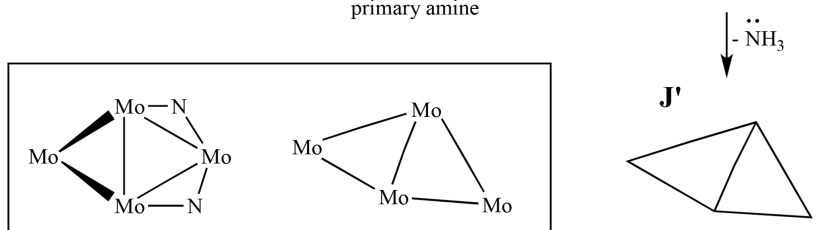

route A: gas phase nitrogen adsorbs side-on to the catalyst and is activated by $21 \%$ by streching of the $\mathrm{N}-\mathrm{N}$ bond; $\mathrm{B}$ : activated $\mathrm{N}_{2} *$ undergoes dissociation through a relatively low activation barrier that results in two bridged-N intermediates; C: $\mathrm{H}_{2}$ adsorbs dissociatively on a $\mathrm{Co}_{8}$ cluster, forming two atomic $\mathrm{H}$ species; $\mathrm{D}$ : $-\mathrm{H}$ chemisorbed on the $\mathrm{Co}_{8}$ cluster reacts with a bridged- $\mathrm{N}$ forming an $\lambda^{3}$-azane intermediate $(>\mathrm{NH})$, which, due to steric congestion, causes the adjacent bridge- $\mathrm{N}$ to move to a hollow position at $\mathrm{Mo}_{3}$ sites; $\mathrm{E}: \mathrm{H}$ reacts with $>\mathrm{NH}$ forming $>\mathrm{NH}_{2}$ at a bridge position formed between $\mathrm{Co}_{32 \mathrm{e}}-\mathrm{Mo}$; $\mathrm{F}$ : another hydrogen chemisorbs dissociatively on $\mathrm{a} \mathrm{Co}_{8}$ cluster; G: the 3f-bound-N to the $\mathrm{Mo}_{3}$ hollow moves due to surface diffusion to the adjacent $\mathrm{Co}-\mathrm{Mo}_{2}$ hollow, while displacing $\mathrm{NH}_{3}$ chemisorbed on the $\mathrm{Co}_{8}$ cluster; $\mathrm{H}, \mathrm{I}$ : $3 \mathrm{f}-$-bound-N at $\mathrm{Co}_{16 \mathrm{~d}}-\mathrm{Mo}_{2}$ hollow moves to adjacent bridge position at $\mathrm{Co}_{8}$ reacting with $\mathrm{H}$ and forming an $\lambda^{3}$-azane intermediate; $\mathrm{J}$ : another hydrogen dissociates on the $\mathrm{Co}_{8}$ cluster forming two $-\mathrm{H}$ species; $\mathrm{K}:-\mathrm{H}$ reacts with $\lambda^{3}$-azane intermediate $(>\mathrm{NH})$ forming a $\lambda^{4}$-azane intermediate $\left(>\mathrm{NH}_{2}\right)$ at the adjacent $\mathrm{Co}_{32 \mathrm{e}}-\mathrm{Mo}$ site; $\mathbf{L}$ : $-\mathrm{H}$ reacts with $>\mathrm{NH}_{2}$ forming surface-adsorbed ammonia $\left(-\mathrm{NH}_{3}\right)$ on the $\mathrm{Co}_{8}$ clusters; $\mathrm{M}$ : ammonia desorbs from the $\mathrm{Co}_{8}$ clusters in a relatively high barrier process; the surface cavity is free and the catalytic cycle resumes, starting from step $\mathbf{A}$.

E-R/MvK (Associative) Ammonia Synthesis Mechanism. In the E-R/MvK mechanism, ammonia is synthesized at the 3f-nitrogen vacancy sites on the $\mathrm{Mo}_{3} \mathrm{~N}$ framework. The active site is shown in the box of Scheme 4 and has some similarities with FeMo-cofactor in nitrogenases: $\mathbf{A}^{\prime}$ : nitrogen adsorbs in an end-on configuration at a 3-fold $\mathrm{N}$-vacancy on the $\mathrm{Mo}_{3} \mathrm{~N}$ framework with $11 \%$ activation; $\mathbf{B}^{\prime}$ : gas phase hydrogen reacts directly in an Eley-Rideal mechanism with surface activated nitrogen forming a trans hydrazine intermediate $\left(>\mathrm{NNH}_{2}\right.$, similar to $\mathrm{Mo}=\mathrm{NNH}_{2}{ }^{29}$ and $\left.\mathrm{Fe}-\mathrm{NNH}_{2}{ }^{30}\right)$, in a low barrier process; $\mathrm{C}^{\prime}$ : hydrogen adsorbs molecularly onto the $\mathrm{Mo}_{3} \mathrm{~N}$ framework adjacent to the nitrogen vacancy site, while trans hydrazine isomerizes into a conformation that can react with $\mathrm{H}_{2} ; \mathbf{D}^{\prime}: \mathrm{H}_{2}$ reacts with the hydrazine-like intermediate forming diazane and $-\mathrm{H} ; \mathbf{E}^{\prime}$ : Diazane readily decomposes due to its positive charge into a tertiary amine and $-\mathrm{H} ; \mathbf{F}^{\prime}:-\mathrm{H}$ reacts with the tertiary amine forming an azane bound to a $\mathrm{Mo}_{3}$ hollow; $\mathbf{G}^{\prime}$ : hydrogen adsorbs molecularly at $\mathrm{Mo}_{3} \mathrm{~N}$ framework adjacent to where previously the nitrogen vacancy site was located; $\mathbf{H}^{\prime}$ : the precursor-mediated adsorbed state of $\mathrm{H}_{2}$ reacts with azane forming primary amine, through a high barrier step;

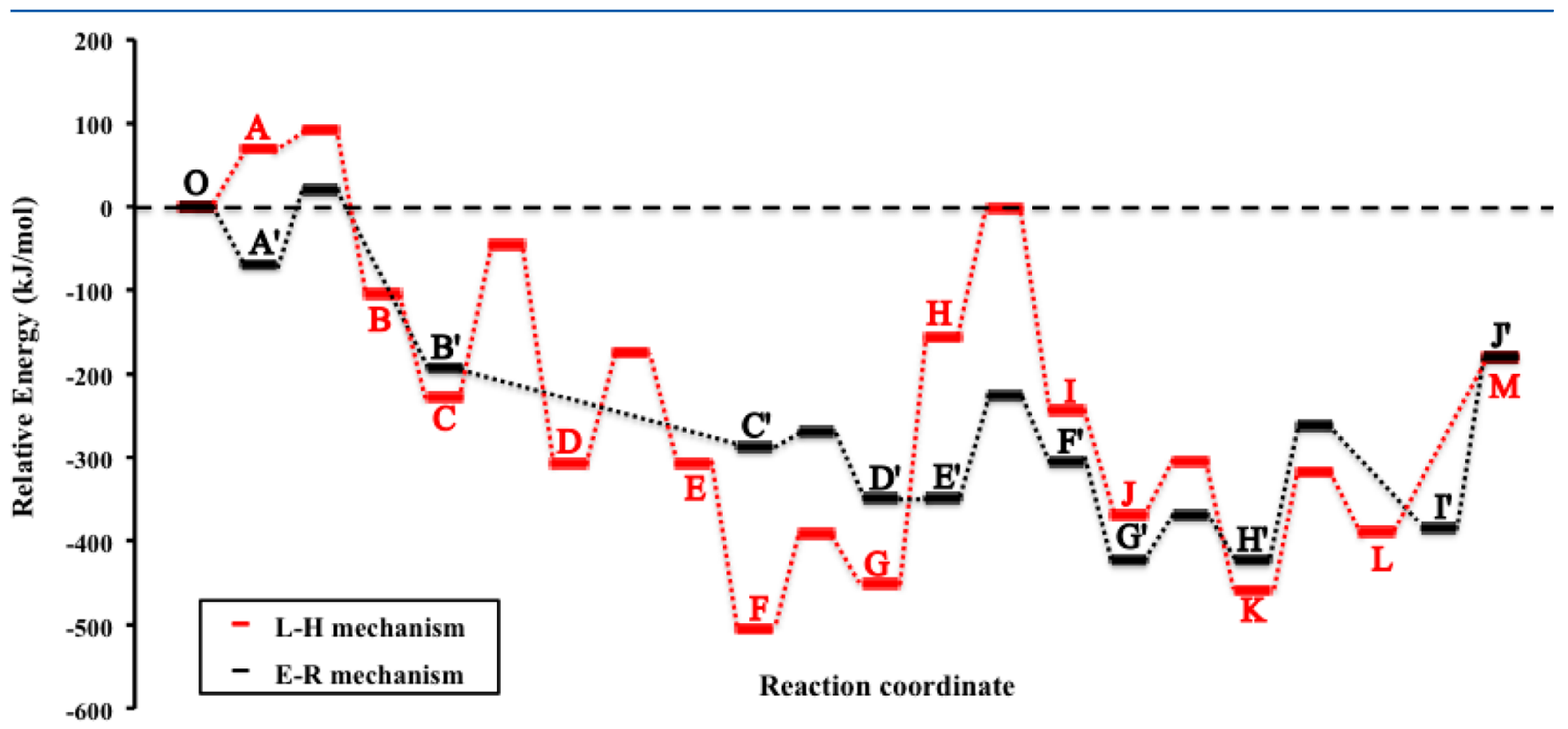

Figure 1. Relative energy diagram of $\mathrm{L}-\mathrm{H}$ (red) and E-R/MvK (black) mechanism for ammonia synthesis on $\mathrm{Co}_{3} \mathrm{Mo}_{3} \mathrm{~N}_{\text {surfaces. }}$ Letter labels given in Schemes 1-4 
$\mathbf{I}^{\prime}$ : the second $-\mathrm{H}$ reacts with the primary amine forming surface chemisorbed ammonia that is bound to a $\mathrm{Mo}_{3}$ hollow site; $\mathbf{J}^{\prime}$ : finally, the second $\mathrm{NH}_{3}$ desorbs through a high barrier step $>200 \mathrm{~kJ} / \mathrm{mol}$.

Comparison of the two distinct mechanisms shows that the barriers for the corresponding hydrogenation steps are lower for the associative $\mathrm{E}-\mathrm{R} / \mathrm{MvK}$ (associative) mechanism and the barrier of the rate-determining step (RDS) is $90 \mathrm{~kJ} \mathrm{~mol}^{-1}$ smaller in the E-R/MvK mechanism. Additionally, the E-R/ MvK mechanism lacks the second and third activation barrier in the L-H mechanism that are high. These results clearly suggest that apart from the conventional L-H (dissociative) mechanism, there is also a mechanism which procceds via diazane and hydrazine intermediates that are formed by a direct associative Eley-Rideal/Mars-van Krevelen mechanism, where molecular hydrogen reacts directly with surface activated nitrogen, in order to form ammonia at considerably milder conditions. Intriguingly, if the mechanism is cycled in two phases, phase I: steps $\mathbf{A}^{\prime}$ through $\mathbf{D}^{\prime}$ as depicted in Scheme 4, and phase II: the catalyst is activated to form nitrogen vacancies, then barriers are $<70 \mathrm{~kJ} / \mathrm{mol}$ for phase I which produces half the stoichiometric amount of ammonia. The second half would be generated by annealing the catalyst to cause desoprtion of $\mathrm{NH}_{3}\left(\Delta H_{\text {des }}=204\right.$ $\mathrm{kJ} \mathrm{mol}^{-1}$ ) and regenerate the amount of nitrogen vacancies on the catalyst surface.

\section{CONCLUSIONS}

We have studied with dispersion-corrected DFT two complete mechanisms for ammonia synthesis on cobalt molybdenum nitride. The first that occurs at surface cavities is a LangmuirHinshelwood (dissociative) mechanism, and the second that occurs at surface nitrogen vacancies is an Eley-Rideal/Marsvan Krevelen (associative) mechanism. We show that, in the Eley-Rideal/Mars van Krevelen mechanism, hydrogen reacts directly with surface activated nitrogen, in order to form ammonia, at considerably milder conditions. The mechanism proceeds via hydrazine and diazane intermediates. This result clearly suggests that, via surface defects, ammonia synthesis activity can be enhanced at milder conditions on one of the most active catalysts for ammonia synthesis.

\section{ASSOCIATED CONTENT}

\section{S Supporting Information}

The Supporting Information is available free of charge on the ACS Publications website at DOI: 10.1021/acs.jpcc.7b12364.

The coordinates of the structure of the various intermediates and transition states (Figure S2) and the detailed barrier calculations (Figure S1) (PDF)

\section{AUTHOR INFORMATION}

\section{Corresponding Authors}

*E-mail: c.zeinalipour-yazdi@ucl.ac.uk.

*E-mail: c.r.a.catlow@ucl.ac.uk.

\section{ORCID $\odot$}

Constantinos D. Zeinalipour-Yazdi: 0000-0002-8388-1549 Justin S. J. Hargreaves: 0000-0003-1926-9299

\section{Notes}

The authors declare no competing financial interest.

\section{ACKNOWLEDGMENTS}

The authors acknowledge financial support from EPSRC (EP/ L026317/1; EP/L02537X/1). The authors acknowledge EPSRC funded computer resources (EP/L000202/1) at ARCHER UK National Supercomputing Service (http:// www.archer.ac.uk) received via our membership of the UK's HPC Materials Chemistry Consortium.

\section{REFERENCES}

(1) Owens, C. P.; Katz, F. E. H.; Carter, C. H.; Oswald, V. F.; Tezcan, F. A. Tyrosine-Coordinated P-Cluster in G. diazotrophicus Nitrogenase: Evidence for the Importance of O-Based Ligands in Conformationally Gated Electron Transfer. J. Am. Chem. Soc. 2016, 138, 10124-10127.

(2) Lukoyanov, D.; Khadka, N.; Yang, Z.-Y.; Dean, D. R.; Seefeldt, L. C.; Hoffman, B. M. Reductive Elimination of $\mathrm{H} 2$ Activates Nitrogenase to Reduce the $\mathrm{N} \equiv \mathrm{N}$ Triple Bond: Characterization of the E4(4H) Janus Intermediate in Wild-Type Enzyme. J. Am. Chem. Soc. 2016, 138, 10674-10683.

(3) Čorić, I.; Holland, P. L. Insight into the Iron-Molybdenum Cofactor of Nitrogenase from Synthetic Iron Complexes with Sulfur, Carbon, and Hydride Ligands. J. Am. Chem. Soc. 2016, 138, 72007211.

(4) Siegbahn, P. E. M. Model Calculations Suggest that the Central Carbon in the FeMo-Cofactor of Nitrogenase Becomes Protonated in the Process of Nitrogen Fixation. J. Am. Chem. Soc. 2016, 138, 1048510495.

(5) Haber, F. Über die Darstellung des Ammoniaks aus Stickstoff und Wasserstoff. Naturwissenschaften 1922, 10, 1041-1049.

(6) Haber, F. Bemerkung zu vorstehender Notiz. Naturwissenschaften 1923, 11, 339-340.

(7) Smil, V. Enriching the Earth: Fritz Haber, Carl Bosch, and the Transformation of World Food Production; MIT Press: Cambridge, MA, 2004.

(8) Saadatjou, N.; Jafari, A.; Sahebdelfar, S. Ruthenium Nanocatalysts for Ammonia Synthesis: A Review. Chem. Eng. Commun. 2015, 202, $420-448$.

(9) Ertl, G. Surface Science and Catalysis-Studies on the Mechanism of Ammonia Synthesis: The P. H. Emmett Award Address. Catal. Rev.: Sci. Eng. 1980, 21, 201-223.

(10) Bowker, M. Modelling of Ammonia Synthesis Kinetics. Catal. Today 1992, 12, 153-163.

(11) Logadóttir, Á.; Nørskov, J. K. Ammonia Synthesis over a $\mathrm{Ru}(0001)$ Surface Studied by Density Functional Calculations. J. Catal. 2003, 220, 273-279.

(12) Zhang, C. J.; Lynch, M.; Hu, P. A Density Functional Theory Study of Stepwise Addition Reactions in Ammonia Synthesis on $\mathrm{Ru}(0001)$. Surf. Sci. 2002, 496, 221-230.

(13) Jacobsen, C. J. H.; Dahl, S.; Clausen, B. S.; Bahn, S.; Logadóttir, A.; Nørskov, J. Catalyst Design by Interpolation in the Periodic Table: Bimetallic Ammonia Synthesis Catalysts. J. Am. Chem. Soc. 2001, 123, 8404-8405.

(14) Blanksby, S. J.; Ellison, G. B. Bond Dissociation Energies of Organic Molecules. Acc. Chem. Res. 2003, 36, 255-263.

(15) Garden, A. L.; Skúlason, E. The Mechanism of Industrial Ammonia Synthesis Revisited: Calculations of the Role of the Associative Mechanism. J. Phys. Chem. C 2015, 119, 26554-26559.

(16) Boisen, A.; Dahl, S.; Jacobsen, C. J. H. Promotion of Binary Nitride Catalysts: Isothermal N2 Adsorption, Microkinetic Model, and Catalytic Ammonia Synthesis Activity. J. Catal. 2002, 208, 180-186.

(17) Jacobsen, C. J. H. Novel Class of Ammonia Synthesis Catalysts. Chem. Commun. 2000, 1057-1058.

(18) Jacobsen, C. J. H.; Dahl, S.; Clausen, B. S.; Bahn, S.; Logadottir, A.; Nørskov, J. Catalyst Design by Interpolation in the Periodic Table: Bimetallic Ammonia Synthesis Catalysts. J. Am. Chem. Soc. 2001, 123, 8404-8405.

(19) Kojima, R.; Aika, K.-I. Cobalt Molybdenum Bimetallic Nitride Catalysts for Ammonia Synthesis. Chem. Lett. 2000, 29, 514-515. 
(20) Kojima, R.; Aika, K.-I. Cobalt Molybdenum Bimetallic Nitride Catalysts for Ammonia Synthesis: Part 1. Preparation and Characterization. Appl. Catal., A 2001, 215, 149-160.

(21) Nørskov, J. K.; Bligaard, T.; Logadóttir, A.; Bahn, S.; Hansen, L. B.; Bollinger, M.; Bengaard, H.; Hammer, B.; Sljivancanin, Z.; Mavrikakis, M.; et al. Universality in Heterogeneous Catalysis. J. Catal. 2002, 209, 275-278.

(22) Zeinalipour-Yazdi, C. D.; Hargreaves, J. S. J.; Catlow, C. R. A. Nitrogen Activation in a Mars-van Krevelen Mechanism for Ammonia Synthesis on Co3Mo3N. J. Phys. Chem. C 2015, 119, 28368-28376.

(23) Zeinalipour-Yazdi, C. D.; Hargreaves, J. S. J.; Catlow, C. R. A. DFT-D3 study of molecular N2 and H2 activation on Co3Mo3N surfaces. J. Phys. Chem. C 2016, 120, 21390-21398.

(24) Abghoui, Y.; Garden, A. L.; Hlynsson, V. F.; Bjorgvinsdottir, S.; Olafsdottir, H.; Skulason, E. Enabling Electrochemical Reduction of Nitrogen to Ammonia at Ambient Conditions Through Rational Catalyst Design. Phys. Chem. Chem. Phys. 2015, 17, 4909-4918.

(25) Abghoui, Y.; Garden, A. L.; Howalt, J. G.; Vegge, T.; Skulason, E. Electroreduction of $\mathrm{N}-2$ to Ammonia at Ambient Conditions on Mononitrides of $\mathrm{Zr}, \mathrm{Nb}, \mathrm{Cr}$, and V: A DFT Guide for Experiments. ACS Catal. 2016, 6, 635-646.

(26) Michalsky, R.; Pfromm, P. H.; Steinfeld, A. Rational Design of Metal Nitride Redox Materials for Solar-Driven Ammonia Synthesis. Interface Focus 2015, 5, 20140084-10.

(27) Michalsky, R.; Avram, A. M.; Peterson, B. A.; Pfromm, P. H.; Peterson, A. A. Chemical Looping of Metal Nitride Catalysts: LowPressure Ammonia Synthesis for Energy Storage. Chem. Sci. 2015, 6, 3965-3974.

(28) Abghoui, Y.; Skúlason, E. Electrochemical Synthesis of Ammonia via Mars-van Krevelen Mechanism on the (111) Facets of Group III-VII Transition Metal Mononitrides. Catal. Today 2017, 286, 78-84.

(29) Rittle, J.; Peters, J. C. An Fe-N2 Complex That Generates Hydrazine and Ammonia via $\mathrm{Fe}=\mathrm{NNH2}$ : Demonstrating a Hybrid Distal-to-Alternating Pathway for N2 Reduction. J. Am. Chem. Soc. 2016, 138, 4243-4248.

(30) Del Castillo, T. J.; Thompson, N. B.; Peters, J. C. A Synthetic Single-Site Fe Nitrogenase: High Turnover, Freeze-Quench 57Fe Mössbauer Data, and a Hydride Resting State. J. Am. Chem. Soc. 2016, 138, 5341-5350. 